\title{
An Unusually Dark Common Trinket Snake, Coelognathus helena (Daudin 1803) (Colubridae), from Nepal
}

\author{
Rohit Giri ${ }^{1}$, Roshan Giri ${ }^{2}$, and Kamal Devkota ${ }^{3}$ \\ ${ }^{1}$ Department of Zoology, Prithvi Narayan Campus, Tribhuvan University, Pokhara, Nepal \\ ${ }^{2}$ Shree Chhorepatan Higher Secondary School, Pokhara, Nepal \\ ${ }^{3}$ Nepal Toxinology Association, Kawasoti, Nawalpur, Nepal (devkotakamal67@gmail.com)
}

Vies

arious unusual color morphs occur in many reptiles (e.g., Bechtel 1978; Lorioux et al. 2008; Strugariu and Zamfirescu 2009). Partial or complete dark coloration of the body might have adaptive benefits in snakes by facilitating thermoregulation, predator avoidance, or reproductive fitness (e.g., Luiselli 1992; Capula and Luiselli 1994; Bittner et al. 2002; Tanaka 2005; Lorioux et al. 2008).

The Common Trinket Snake (Coelognathus helena) has been recorded from various districts in Nepal (Schleich and Kästle 2002; Shah and Tiwari 2004). It is active both by day and night and feeds mainly on rats, mice, and squirrels but also preys on frogs, lizards, and snakes (Schleich and Kästle 2002; Shah and Tiwari 2004; Whitaker and Captain 2004). Typical dorsal coloration (Fig. 1) is olive to dark brown with two black stripes on the neck and light bands on the forebody, two prominent dark brown or black stripes that continue onto the tail, and a pearly white venter (Shah and Tiwari 2004; Whitaker and Captain 2004). At $1041 \mathrm{~h}$ on 20 February 2020, we encountered an unusually dark juvenile (total length ca. $300 \mathrm{~mm}$ ) Common Trinket Snake (Fig. 1) during a rescue call in Buddhachowk, Pokhara, Kaski, Nepal (2812'18.93"N, 8359'58.45"E; elev. $866 \mathrm{~m}$ asl).

Aberrant colors and patterns have been documented in various species of Indian snakes (Mahabal and Thakur 2014). Wall (1913) described an "almost blackish" C. helena from Anamallays in southern India, on the basis of which Mahabal and Thakur (2014) included the species in their review. To the best of our knowledge, the observation reported herein represents the first documented record of an unusually dark Common Trinket Snake from Nepal.

\section{Literature Cited}

Bechtel, H.B. 1978. Color and pattern in snakes (Reptilia, Serpentes). Journal of Herpetology 12: 521-532.

Bittner, T.D., R.B. King, and J.M. Kerfin. 2002. Effects of body size and melanism on the thermal biology of Garter Snakes (Tamnophis sirtalis). Copeia 2002: 477-482.

Capula, M. and L. Luiselli. 1994. Reproductive strategies in alpine adders, Vipera berus. The black females bear more often. Acta Ecologica 15: 207-214.

Lorioux, S., X. Bonnet, F. Brischoux, and M. De Crignis. 2008. Is melanism adaptive in sea kraits? Amphibia-Reptilia 29: 1-5.

Luiselli, L. 1992. Reproductive success in melanistic adders: A new hypothesis and some considerations on Andren and Nilson's (1981) suggestions. Oikos 64:
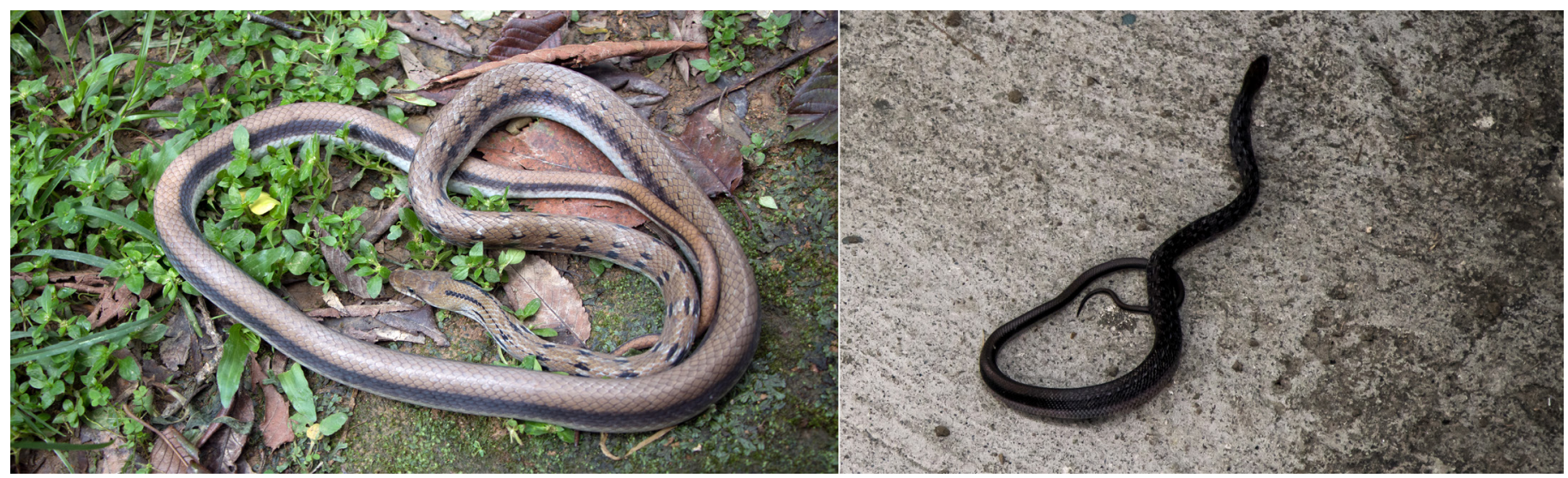

Fig. 1. Typical coloration of a Common Trinket Snake (Coelognathus helena) (left) and an unusually dark individual from Nepal (right). Photographs by Rohit Giri. 


\section{1-604.}

Mahabal, A. and S. Thakur. 2014. Intances of aberrant colors and patterns among the Indian herpetofauna: A review. Russian Journal of Herpetology 21: 80-88.

Schleich, S.H. and W. Kästle (eds.). 2002. Amphibians and Reptiles of Nepal: Biology, Systematics, Field Guide. A.R.G. Gantner Verlag KG, Ruggell, Liechtenstein.

Shah, K.B. and S. Tiwari. 2004. Herpetofauna of Nepal: A Conservation Companion. IUCN Nepal, Patan, Nepal.

Strugariu, A. and S.R. Zamfirescu. 2009. A melanistic adder (Vipera berus) neo- nate born from a cryptic female: Are black vipers born heavier? North-Western Journal of Zoology 5: 218-223.

Tanaka, K. 2005. Thermal aspects of melanistic and striped morphs of the snake Elaphe quadrivirgata. Zoological Science 22: 1173-1179.

Wall, F. 1913. A popular treatise on the common Indian Snakes. Part 19. Coluber helena. Journal of the Bombay Natural History Society 22: 22-28 + plate 19.

Whitaker, R. and Captain, A. 2004. Snakes of India. The Field Guide. Draco Books, Chennai, India. 